\title{
Correction to: Hiding in the Dark: Local Ecological Knowledge about Slow Loris in Sarawak Sheds Light on Relationships between Human Populations and Wild Animals
}

\author{
Priscillia Miard ${ }^{1}$ (D) K. A. I. Nekaris ${ }^{1} \cdot$ Hatta Ramlee $^{2}$ \\ Published online: 30 April 2019 \\ (C) Springer Science+Business Media, LLC, part of Springer Nature 2019
}

\section{Correction to: Human Ecology (2017) 45:823-831}

https://doi.org/10.1007/s10745-017-9954-x

The article Hiding in the dark: Local ecological knowledge about slow loris in Sarawak sheds light on relationships between human populations and wild animals, written by Priscillia Miard, K. A. I. Nekaris and Hatta Ramlee, was originally published electronically with open access.

With the author(s)' decision to step back from Open Choice, the copyright of the article changed on April 2019 to () Springer Science+Business Media, LLC, part of Springer Nature 2019 and the article is forthwith distributed under the terms of copyright.

The original article has been corrected.

Publisher's Note Springer Nature remains neutral with regard to jurisdictional claims in published maps and institutional affiliations.

The online version of the original article can be found at https://doi.org/ 10.1007/s10745-017-9954-x

Priscillia Miard

priscillia.miard@gmail.com

1 Nocturnal Primate Research Group, Oxford Brookes University, Oxford, UK

2 Nature Conservation \& Constitution Division (NCCD), Forest Department Sarawak, Kuching, Malaysia 